\title{
PERAN PEREMPUAN DI DALAM DUNIA POLITIK
}

\author{
Ni Luh Ketut Sukarniti \\ Fakultas Ilmu Sosial dan Ilmu Politik, Universitas Mahendradatta - Denpasar \\ e-mail : sukarnitiagung02@gmail.com
}

\begin{abstract}
Abstrak - Politik merupakan kegiatan dalam suatu sistem atau Negara yang menyangkut proses penentuan tujuan dari sistem tersebut. Kehidupan politik di suatu Negara khususnya Indonesia sangatlah kompleks. Tampilnya perempuan di dunia politik sudah berlangsung dari jaman dahulu mulai dari zaman kerajaan - kerajaan di Nusantara

Tuntunan persamaan hak perempuan dalam berbagai bidang kehidupan merupakan agenda di zaman sekarang ini. Prestasi dan keterampilan yang ditunjukkan kaum perempuan selama ini sudah memunculkan anggapan bahwa antara laki - laki tidak terdapat banyak perbedaan. Prestasi dan keterampilannya dapat terlihat dari peranan perempuan dalam kehidupan politik di Negara kita. Kekuatan berupa ketegaran, ketegasan sekaligus menjadi syarat untuk menjadi pemimpin.

Beban dan tanggung jawab seorang wanita pemimpin lebih besar dari tanggung jawab lakilaki, dimana wanita berperan ganda yang juga memiliki tanggung jawab baik ibu rumah tangga maupun tanggung jawab kewanitaan lainnya. Kesejajaran antara wanita dengan laki - laki merupakan suatu usaha yang tidak sia - sia apabila wanita berusaha sesuai kemampuannya, untuk dapat bersaing dengan kaum laki - laki sesuai dengan sifat kewanitaannya. Dari hal tersebut perempuan banyak memiliki hambatan - hambatan untuk terjun ke kancah politik. Mulai dari kurangnya kesadaran untuk ikut berpartisipasi ke dalam dunia politik.

Untuk mengatasi hambatan - hambatan yang dimiliki oleh perempuan di dalam dunia politik dan harus mengadakan upaya peningkatan partisipasi perempuan di kancah dunia politik dengan memberikan pendidikan sejak dini, sehingga perempuan menjadi mengerti. Keterlibatan perempuan di dunia politik masih sangat belum berimbang, Oleh karena itu kebijakan - kebijakan kaum laki - laki kurang perspektif gender sehingga keputusan sering kali tidak memihak terhadap perempuan, tidak memperhatikan kaum perempuan dan tidak membuat perempuan semakin berkembang.
\end{abstract}

Kata Kunci: peran, perempuan dan dunia politik.

\begin{abstract}
Politics is an activity in a system or State that involves the process of determining the purpose of the system. Political life in a country especially Indonesia is very complex. The appearance of women in the political world has been going on from ancient times starting from the days of the kingdoms in the archipelago.

The equality of women's rights in various fields of life is an agenda in this day and age. The achievements and skills shown by women have led to the notion that there are not many differences between men. His achievements and skills can be seen from the role of women in political life in our country. Strength in the form of toughness, firmness as well as being a condition for becoming a leader.

The burden and responsibility of a woman leader is greater than men's responsibility, where women play a dual role who also has responsibilities both housewives and other female responsibilities. Alignment between women and men is an effort that is not in vain if women try according to their abilities, to be able to compete with men in accordance with their femininity. From this, many women have barriers to entering the political arena. Starting from a lack of awareness to participate in politics.

To overcome the obstacles that women have in politics and must make efforts to increase women's participation in the political arena by providing education from an early age, so that women can understand. The involvement of women in the political world is still very unbalanced, therefore men's policies are lacking in a gender perspective so that decisions often do not favor women, do not pay attention to women and do not make women more developed.
\end{abstract}

Keywords: Role, Women and Political World 
PENDAHULUAN

Kehidupan politik yang berlangsung di suatu Negara sangatlah kompleks, mulai dari pembuatan keputusan, berfungsinya lembaga-lembaga politik, praktek-praktek politik dan sebagainya. Politik merupakan kegiatan dalam suatu sistem Negara yang menyangkut proses penentuan tujuan dari sistem tersebut.

Di era globalisasi terdapat kebutuhan yang pasti untuk mendefenisikan peran perempuan dalam arena sosial dan politik. Tampilnya perempuan di panggung politik Indonesia sudah terjadi sejak zaman kerajaan-kerajaan di Nusantara. Perjuangan fisik melawan kolonialisme Belanda juga banyak tampil tokoh-tokoh perempuan. Beberapa diantaranya seperti Dewa Agung Istri Kaniya adalah tokoh perempuan yang memimpin perang Kusamba, di wilayah Kerajaan Klungkung Bali, yang dijuluki "wanita besi" dari Bali oleh pihak pemerintah Belanda. Cut Nyak Dien dan Cut Meutia dari Aceh, Marta Tehahahu dari Maluku, Emmy Saelan dari Sulawesi Selatan dan lain-lain. Di Jawa Tengah R.A Kartini dikenal sebagai tokoh yang memperjuangkan kesetaraan perempuan khususnya dalam bidang pendidikan. Di Jawa Barat nama Dewi Sartika dikenal sebagai tokoh yang juga bergerak dalam meningkatkan pendidikan perempuan. Keikutsertaan perempuan dalam perjuangan Bangsa Indonesia untuk memperoleh kemerdekaan, membebaskan Bangsa dari penjajahan telah tertulis dalam berbagai dokumen Bangsa ini.

Studi partisipasi politik bila dikaitkan dengan wanita, ini membawa implikasi bahwa wanita sebagai sosok yang patut diperhitungkan dan diteliti secara tersendiri atau diperlakukan sebagai aktor atau subyek yang eksklusif dalam politik. Meningkatnya kepedulian terhadap partisipasi politik wanita menunjukkan bahwa para ilmuwan dan para pengambil keputusan, kini mulai menyadari bahwa persoalan mengenai pembangunan tidak terlepas dari peran wanita dalam segala aspek pembangunan.

Bertolak dari pemahaman terhadap pentingnya keterlibatan wanita sebagai sumberdaya yang potensial untuk mencapai tujuan nasional, maka studi tentang partisipasi politik wanita menjadi tabu untuk dibahas. Segala problematika per- empuan itu sebenarnya berhulu pada masyarakat yang masih sangat patriaksis atau mengedepankan laki-laki. Akibatnya kebijakan-kebijakan yang dibuat oleh Negara akhirnya juga tidak mengakomodir kebutuhan perempuan.

\section{PEMBAHASAN}

\subsection{Partisipasi Politik Perempuan}

Secara etimologis partisipasi diartikan sebagai kegiatan orang atau kelompok orang untuk ikut secara aktif di dalam dunia politik, yaitu dengan jalan memilih pemimpin Negara secara langsung maupun tidak langsung mempengaruhi kebijakan Negara. Adapun menurut Huntington dan Nelson partisipasi politik (1990) adalah kegiatan warga Negara yang bertindak pribadi-pribadi untuk mempengaruhi keputusan oleh pemerintah.

Berbicara tentang perempuan dan politik, merupakan bahasan yang menarik. Sebab, peran politik perempuan dari perspektif kalangan feminism radikal adalah dimana terjadinya transformasi total peran perempuan di ranah domestik ke ranah publik, atau dalam bahasa populernya kesetaraan gender.

Sudah waktunya memang, perspektif gender masuk kesegala lini kehidupan terutama dalam pengambilan keputusan dan kebijakan pemerintah. Jika hal tersebut selama ini belum sempat dilakukan dikarenakan kehidupan sosio politik selama ini di Indonesia hanya dilihat dari kaca mata laki-laki. Sementara kaum perempuannya sendiri malah kian terpinggirkan dan dianggap tidak layak memasukinya karena politik dianggap sebagai dunia yang kejam dan kotor. Padahal politik perempuan justru berbeda dengan politik laki-laki.

Keterlibatan wanita di kancah politik bukan hal yang baru. Dalam sejarah perjuangan kaum wanita, partisipasi wanita dalam pembangunan, telah banyak kemajuan dicapai terutama di bidang pendidikan, ekonomi, lembaga kenegaraan, dan pemerintahan.

Berbicara tentang partisipasi politik wanita, tentu saja kita tidak dapat menghindarkan diri dari diskusi tentang partisipasi politik menurut disiplin ilmu politik. Mely G. Tan (1992, dalam Yulfita, 1995:1) membedakan partisipasi politik dalam dua aspek, yaitu dalam arti sempit dan luas. Dalam arti sempit yaitu berupa keikutser- 
taan dalam politik praktis dan aktif dalam segala kegiatannya, sedangkan dalam arti luas, berupa keikutsertaan secara aktif dalam kegiatan yang mempunyai kemampuan, kesempatan dan kekuasaan dalam pengambilan keputusan yang mendasar serta menyangkut kehidupan orang banyak.

Dalam sebuah lingkungan nyata, konstribusi politik perempuan haruslah diletakkan dalam suatu cara bahwa aktivitas-aktivitas kolektif didasarkan atas sebuah kehendak bebas, sukarela, sadar, dan aktif. Inilah sebuah situasi ketika individu-individu masyarakat dan mengatur urusan-urusan sosial (baik langsung maupun tidak) serta membantu membentuk kehidupan masyarakat.

Dalam sejarah perjuangan kaum wanita Indonesia, kita mengenal tokoh-tokoh seperti R.A Kartini, Dewi Sartika, Nyi Ageng Serang dan sebagainya. Mereka memperjuangkan hak-hak wanita untuk dapat memperoleh pendidikan setara dengan pria. Di bidang lain ada wanita yang berjuang untuk merebut kemerdekaan seperti Cut Nyak Dien, Maria Tiahahu, Yolanda Marinis. Organisasi wanita telah lama ada sebelum kemerdekaan, bahkan pada tanggal 22 Desember 1928 mereka mengadakan kongres I. Bahkan kini terdapat 66 unit organisasi wanita yang berhimpun dalam Kowani (Kongres Wanita Indonesia).

Secara Undang-Undang Dasar 1945 (UUD 1945) tidak membedakan laki-laki dan perempuan serta menjamin bagi warga Negaranya tentang persamaan hak dan kewajiban di bidang politik. Pada tahun 1978 persamaan hak, tanggung jawab dan kesempatan tersebut ditekankan secara eksplisit di dalam Garis-Garis Besar Haluan Negara (GBHN) Kepedulian Indonesia terhadap persamaan hak ini juga tercermin dengan ikut sertanya menandatangani konvensi mengenai penghapusan segala bentuk deskriminasi terhadap perempuan pada tahun 1980 dan diretivikasi tahun 1984 melalui Undang-Undang (UU) No. 7 Tahun 1984.

Dalam segi Ideologi dan Hak Asasi Manusia, perempuan mempunyai kedudukan yang sama dengan laki-laki. Perempuan dan laki-laki mempunyai hak, kedudukan dan kesempatan yang sama untuk memperoleh kesehatan, pendidikan, pekerjaan, hak untuk hidup, hak kemerdekaan pikiran, hak untuk tidak disiksa, hak untuk diakui sebagai pribadi dihadapan hukum, hak untuk berserikat, berorganisasi, berpolitik, dan berbagai hak universal yang dilindungi oleh hukum. Singkat kata semua hak yang dimiliki laki-laki tak ubahnya duduk sama rendah dan berdiri sama tinggi. Perempuan dan laki-laki mempunyai kedudukan yang sama, yang dijamin dan dilindungi oleh Negara.

Dalam lingkup rumah tangga laki-laki berperan sebagai kepala rumah tangga dan perempuan ibu rumah tangga. Meskipun beberapa ahli menyatakan larangan total bagi aktivitas perempuan dalam wilayah ini. Sementara, pada saat yang sama, selainnya menyisakan ruang bagi perubahan dalam aturan klasik ini, sebuah perubahan yang di dasarkan atas ruang dan waktu. Sejauh hukum syariat tidak mengingkari peran perempuan dalam masyarakat dan mendelegasikan mereka posisi yang netral, kesetaraan gender dalam ruang sosial, perempuan memiliki hak untuk partisipasi dalam ruang politik. Perempuan bebas mengekspresikan pandangannya dan memberikan persetujuan atau kritiknya terhadap berbagai kebijakan pemerintah.

\subsection{Hambatan-hambatan Partisipasi Politik Perempuan}

Peluang dan tantangan dalam politik telah kita ketahui. Namun akan sulit bagi perempuan untuk memanfaatkan peluang tersebut jika perempuan sendiri tidak mengetahui hambatan-hambatan baik terdapat di dalam dirinya maupun yang ada diluar dirinya. Hambatan-hambatan inilah yang sering dihadapi perempuan di seluruh dunia merasakan dirinya kurang terwakili dalam parlemen atau institusi-institusi pembuat kebijakan. Kendala pokok yang seringkali dipergunakan sebagai alasan lemahnya partisipasi politik wanita, dapat dikelompokkan memjadi dua yaitu: hambatan internal dan eksternal.

Hambatan internal, pertama: kurangnya kesadaran sebagian besar perempuan untuk berkiprah dan berpartisipasi dalam kegiatan politik. Kurangnya kesadaran ini dikarenakan sosio-kultural mereka yang belum memungkinkan bisa aktif menyuarakan dan menyampaikan keinginan-keinginan di bidang politik. Kedua: aktivitas politik dianggap tidak layak untuk perem- 
puan, karena sifat-sifatnya yang berjauhan dari citra untuk wanita. Dunia politik dianggap "kera", "kotor", "main kayu", dan penuh muslihat, sehingga dianggap tidak cocok untuk citra wanita. Pandangan ini membuat dunia politik itu tertuju pada laki-laki, bahkan dianggap tabu untuk wanita. Konsekuensi lebih lanjut wanita menjadi enggan memasukinya. Wanita menjadi pasif dalam berpolitik. Ketiga: lingkungan sosial budaya yang kurang mendukung pengembangan potensi wanita, antara lain wawasan orang tua, adat, penafsiran terhadap ajaran agama yang tidak tepat, tingkat pendapatan keluarga, dan sistem pendidikan yang diskriminatif. Masih lekatnya budaya tradisional dan kecilnya akses wanita pada penguasaan faktor sosial ekonomi, menyebabkan terbentuknya pemikiran dalam diri wanita bahwa memang sewajarnya mereka berada di belakang pria.

Dominasi budaya patriarkhi seolah memberi garisan tegas bahwa antara perempuan dan politik, merupakan dua dunia yang berbeda dan tidak dapat bersinergi satu dengan yang lainnya. Dunianya perempuan adalah di rumah yang meliputi wilayah domestik, mengurus anak-anak, kalaupun berkarir di luar rumah maka pekerjaan / karir bukanlah hal yang utama. Perempuan diharuskan siap memainkan peran ganda, sebagai ibu dan perempuan bekerja. Sedangkan politik adalah tempat yang cocok bagi laki-laki karena penuh dengan intrik-intrik berbahaya, serta identik dengan uang dan kekuasaan.

Dalam pandangan Walby, meskipun sudah terdapat banyak pencapaian kaum wanita terhadap hak-hak sipil mereka misalnya hak mendapatkan pekerjaan, kemudahan bercerai, tunjangan bagi kaum wanita non-pekerja, sensor pornografi, kemudahan mendapatkan alat kontrasepsi dan aborsi, serta hukum yang memudahkan bagi kaum wanita untuk meninggalkan kaum pria yang melakukan kekerasan tetap saja bersifat patriarchal, sebagaimana halnya dengan kapitalis dan rasis. Kebijakan-kebijakan Negara belum lama diarahkan pada upaya untuk meyakinkan kaum wanita akan ranah privat dari rumah, dengan sedikit upaya yang nyata untuk memajukan posisi kaum wanita diranah publik. Kaum wanita masih sedikit mendapatkan upah dibanding kaum pria dan peluang yang sama dalam legislasi sering tidak diperkuatkan. Kaum wanita dalam keluarga orang tua tunggal memperoleh sedikit manfaat dari Negara dan kaum wanita masih disakiti dengan ketersediaan pornografi yang semakin besar dimasyarakat.

Kendala eksternal menurut Afan Gaffar (1991:25) antara lain dari birokrasi yang paternalistik, pola pembangunan ekonomi dan politik yang kurang seimbang dan kurang berfungsinya partai politik.

\subsection{Upaya Peningkatan Partisipasi Poli- tik Perempuan}

Untuk mendorong peningkatan dalam partisipasi politik perempuan, perlu pemahaman dan analisis secara menyeluruh sehingga dihasilkan suatu rekomendasi kebijaksanaan yang tepat.

Pertama, harus dimulai pendidikan dari keluarga, bahwa berkiprah serta berpartisipasi di dunia politik adalah salah satu bagian yang penting untuk membangun masyarakat, Bangsa dan Negara.

Kedua, anak perempuan yang mengikuti pendidikan sejak disekolah menengah sampai Universitas, sebaiknya didorong untuk aktif mengikuti organisasi seperti OSIS, Badan Eksekutif Mahasiswa (BEM), dan organisasi ekstra universitas seperti HMI, GMNI, organisasi pemuda seperti KNPI, dan organisasi kemasyarakatan seperti Muhammadiyah, NU, dan lain - lain. Maka berarti secara sadar kaum perempuan telah mempersiapkan diri menjadi pemimpin. Sekarang ini, perempuan yang banyak berkiprah di dunia politik adalah mereka yang sejak menjadi pelajar dan mahasiswa telah aktif diberbagai organisasi pelajar dan organisasi kemahasiswaan.

Ketiga, melakukan advokasi terhadap kaum perempuan supaya terpanggil untuk berpartisipasi dalam kancah politik.

Keempat, mempersiapkan anak - anak perempuan sejak dini untuk terpanggil dan tertantang memasuki dunia politik. Dengan cara ini, maka dimasa depan akan semakin banyak perempuan yang berkiprah dan berpartisipasi dalam kancah politik.

Kelima, memberi pencerahan, penyadaran dan dorongan kepada kaum perempuan supaya dalam berbagai kegiatan politik seperti berpartisipasi dalam kampanye, pemilih, menjadi calon legislatif, calon Gubernur / Wakil Gubernur, Walikota / Wakil Walikota, Bupati / Wakil Bupati dan 
lain sebagainya.

Beberapa peluang bagi perempuan untuk dapat meningkatkan kualitas perannya dibidang politik antara lain:

- Pasal 17 dan 21 UUD 1945;

- GBHN yang sejak tahun 1978;

- Konferensi-konferensi wanita se-dunia.

Peluang-peluang yang mendukung tersebut, kaum perempuan sebenarnya mempunyai peluang dan kesempatan yang besar untuk bisa berkiprah dan berpartisipasi dalam dunia politik. Meskipun memang pada akhirnya akan dikembalikan kepada wanita untuk memanfaatkan atau tidak. Di era Orde Reformasi, peluang perempuan semakin terbuka untuk menjadi pemain, bukan lagi sekedar partisipan pasif. Setidaknya, ada empat faktor yang memberikan harapan terbukanya peluang kepada kaum perempuan untuk meningkatkan perannya di dunia politik.

Pertama, semakin banyak perempuan yang berpendidikan dan memiliki kesadaran pentingnya perempuan terjun ke dunia politik untuk berpartisipasi membangun Indonesia yang maju dan sejahtera.

Kedua, tren politik nasional di era Orde Reformasi yang memberi alokasi 30 persen kepada kaum perempuan untuk menjadi calon anggota legislatif.

Ketiga, mengingat besarnya potensi yang ada pada wanita Indonesia yang secara kuantitas lebih besar daripada pria, maka sewajarnyalah bila peluang dan potensi tersebut tidak disia - siakan.

Wanita dalam pengembangan kiprahnya sebagai warga Negara, mempunyai harapan sebagai pemilik masa depan Bangsa, yang secara fungsional harus mampu menempatkan diri sebagai pemimpin tenaga pembaharu, dinamisator dan katalisator untuk pembangunan nasional. Oleh karena itu wanita dalam menghadapi tantangan abad XXI, harus mampu membekali dirinya dengan ilmu, teknologi dan berbagai macam kemampuan serta keterampilan di berbagai bidang kehidupan seperti politik, ekonomi, sosial dan budaya Bangsanya.

Upaya untuk mengentaskan ketidakberdayaan wanita yang berkaitan dengan kualitas perannya dibidang politik, yang pertama adalah menghilangkan segala bentuk diskriminasi terhadap wanita di pentas politik untuk mengaktualisasikan kemampuannya. Hal tersebut tidak hanya selaras dengan tujuan pembangunan nasional, tetapi juga karena jumlah wanita Indonesia adalah separuh jumlah penduduk Indonesia. Oleh karena itu sangatlah wajar bila ada wakil yang dapat menyuarakan aspirasi politik mereka.

Peran wanita Indonesia di pentas politik sudah waktunya mendapat porsi yang proporsional. Seyogyanya tidak ada lagi ucapan yang meragukan kemampuannya untuk tampil di pentas politik, oleh karena itu harus ada gerakan yang mendorong wujudnya kebijakan pemerintah yang memiliki kepekaan gender.

Untuk mencapai keberhasilan gerakan tersebut, memerlukan akses wanita terhadap pembuatan keputusan nasional. Hal tersebut sesuai pernyataan Senator Leticia Ramos Shahani, ketua delegasi Philipina pada konferensi ke-empat PBB mengenai wanita bahwa "akses terhadap pembuatan keputusan sangatlah penting bagi siapapun yang menghendaki reformasi untuk memasukkan dunia politik bagi wanita." (Angkatan Bersenjata, 14 September 1995).

Mengingat masih kecilnya akses tersebut dan masih banyaknya prasangka di dunia yang menghalangi pemilihan wanita sebagai anggota parlemen, maka menurut Chris Fletcher anggota parlemen Selandia Baru mengatakan bahwa Panggung Aksi Konferensi Ke- empat PBB mengenai wanita bulan September 1995, harus mendesak pemerintah agar bersedia menyisihkan sedikitnya 50\% kursi di parlemen bagi wanita pada tahun 2005 .

Dari sisi keberanian wanita, perlu adanya penyadaran terhadap wanita bahwa pola struktural hubungan laki - laki dan perempuan yang terbangun selama ini harus dirombak. Kaum wanita harus sadar akan hak asasinya, sehingga pola pemikiran dominasi laki-laki yang selama ini mengakar dalam kehidupannya perlu dirubah dan diwujudkan dalam kemitrasejajaran.

Upaya menuju ke arah cita-cita kesetaraan ini memang tidak mudah, bahkan rumit. Upaya tersebut memerlukan keterlibatan semua pihak yakni kaum wanita sendiri, kaum laki-laki, dan unsur-unsur kebijakan Nasional yang berwawasan gender. Proses penyadaran harus dilakukan secara simultan di kalangan baik laki-laki maupun perempuan. 


\subsection{Perempuan dalam Dunia Politik}

Dalam perkembangan sejarah perpolitikan bangsa Indonesia dan Negara berkembang pada umumnya, perempuan memang masih dipandang terlambat dalam keterlibatannya di dunia politik. Dari pemilu 1999 kita dapat melihat fenomena penolakan perempuan menjadi presiden dengan adanya fatwa yang dikeluarkan oleh salah satu partai berisi bahwa Presiden pemimpin RI adalah putra beragama Islam. Di tahun yang sama pula ketua partai lain mengatakan bahwa perempuan boleh menjadi Presiden jika laki-laki tidak becus memimpin Negara ini. Padahal semua itu jelas-jelas melanggar ketentuan dalam konvensi CEDAW (convention the all form of discrimination against women) atau dalam bahasa Indonesianya berarti konvensi-konvensi internasional tentang penghapusan segala bentuk kekerasan terhadap kaum perempuan. Dimana Indonesia itu sendiri telah mempunyai undang-undang yang berkaitan dengan hal tersebut yaitu
UU No. 7 tahun 1984 terutama pasal 7 yang berisi tentang hak perempuan untuk dipilih dalam sebuah pemilihan umum dan hak perempuan untuk turut merumuskan dan menjabat Negara.

Politik laki-laki mengutamakan uang, kuasaan dan kedigdayaan, sementara politik perempuan adalah politik yang sederhana dan terjadi setiap hari. Statistik di bawah ini adalah komposisi para pemegang kebijakan dari tingkat pusat (DPR) hingga daerah (DPRD II) yang menunjukkan ketidak setaraan yang serius. Menurut sensus yang dilaksanakan Biro Pusat Politik (BPS) tahun 2000, jumlah perempuan di Indonesia adalah 1001.625.816 jiwa atau 51\% dari seluruh populasi atau lebih banyak dari total jumlah penduduk di ketiga Negara yaitu Malaysia, Singapura dan Filipina. Namun jumlah besar tersebut tidak tampak pada keterlibatan perempuan di dalam dunia politik, sebagai mana tampak dalam tabel berikut:

\begin{tabular}{|l|c|c|c|}
\hline \multicolumn{1}{|c|}{ LEMBAGA } & JUML PEREMP & JUML LAKI-LAKI & PERSENTASE \\
\hline MPR & 18 & 177 & 9,2 \\
\hline DPR & 45 & 455 & 9,0 \\
\hline MA & 7 & 40 & 14,8 \\
\hline BPK & 0 & 7 & 0,0 \\
\hline KPU & 2 & 9 & 18,1 \\
\hline GUBERNUR (DATI I) & 0 & 10 & 0,0 \\
\hline BUPATI (DATI II) & 5 & 331 & 1,5 \\
\hline
\end{tabular}

Sumber: CETRO

Dari tabel diatas, keterlibatan perempuan dalam pengambilan keputusan sangat dirasakan belum berimbang. Oleh karena itu kebijakan-kebijakan kaum laki-laki kurang berstetif gender sehingga keputusan sering kali tidak memihak terhadap perempuan, tidak memperhatikan kaum perempuan dan tidak membuat perempuan semakin berkembang. Walaupun kuantitas perempuan di legislatif belum tentu menjamin taraf hidup perempuan. Kenyataan di lapangan banyak membuat perempuan semakin tenggelam pada sektor-sektor yang strategis, hal ini meng- akibatkan posisi perempuan senantiasa membuat perempuan berada dalam posisi yang terpuruk. Oleh karena itu perlu adanya upaya strategis untuk mengangkat keberadaan perempuan di dalam dunia politik. Salah satu caranya adalah menempatkan perempuan di tempat yang strategis seperti di legislatif, eksekutif dan yudikatif. Dengan demikian perempuan dapat terlibat aktif di dalam dunia politik, termasuk memberikan pertimbangan-pertimbangan yang mengedepankan kepentingan perempuan. 


\section{PENUTUP}

Berdasarkan uraian pembahasan di atas, maka dapat ditarik kesimpulan sebagai berikut:

- Potensi sumber daya wanita Indonesia sangatlah besar dan merupakan aset Bangsa yang tidak ternilai harganya dan perlu dibina, dikembangkan serta diberi kesempatan yang sama dengan laki-laki sebagai subjek dan obyek pembangunan.

- Secara yuridis formal Indonesia tidak membedakan antara laki-laki dan wanita dalam bidang politik. Namun karena kendala baik yang bersumber dari intern wanita itu sendiri maupun faktor eksternal, maka partisipasi politik wanita dalam pertumbuhannya jauh lebih rendah dibanding partisipasi politik laki-laki.

- Peningkatan partisipasi politik wanita dapat diupayakan melalui pemanfaatan peluang yang ada, baik yang sudah diatur dalam GBHN maupun lembaga-lembaga tingkat internasional yang menangani masalah wanita. Disamping itu perlu adanya redefinisi, reorientasi dan revitalisasi pendidikan politik agar lebih kondusif bagi pembinaan, pertumbuhan dan peningkatan partisipasi politik bagi wanita pada khususnya dan semua Negara pada umumnya.

\section{Daftar Pustaka}

Roger.M.Keesing, 1981, Antropologi Budaya. Jakarta, Erlangga.

Rosalind Horton dan Sally Simons, Wanita-wanita yang Mengubah

Husein Hakeem Ali, 2005, Membela Perempuan. Jakarta, Al-Huda. 